Sign Systems Studies 49(3/4), 2021, 608-615

\title{
Jaan Kaplinski and his contacts with the Tartu-Moscow School of Semiotics
}

\author{
Ekaterina Velmezova, Kalevi Kull, Ene-Reet Soovik
}

\begin{abstract}
Как тихо все в Кяэрику каким молчанием молчат окна лестницы и площадки молчит потрескавшийся асфальт под муравьиными тропами как где-то молчат все кто тут был говорил и читал наизусть стихи как молчат Юрий Михайлович Александр Моисеевич молчит Линнарт и Хальянд не скажет ни единого слова и где-то куда я еще не вернулся я еще там мартовское солние режет-колет мои босые ноги а я молодой и влюбленный убегаю дальше и дальше по колючему снегу навстречу нашему соборному молчанию ${ }^{1}$
\end{abstract}

Kaplinski 2014: 63

\begin{abstract}
Jaan Kaplinski (1941-2021), Estonian poet, essayist and public intellectual, sadly passed away earlier this year. To commemorate him, we publish some excerpts from a conversation with him that was recorded in 2018 and in which, among other topics, we also talked about Kaplinski's relationship with semiotics and his personal contacts with eminent scholars of the Tartu-Moscow School.
\end{abstract}

Jaan Kaplinki (22 January 1941 - 8 August 2021), internationally acclaimed Estonian poet, essayist, and culture critic, recipient of the European Prize for Literature $(2015)^{2}$ was known for his focus on global issues, including academic concerns. Kaplinski was born in Tartu and studied French language and literature at the University of Tartu, graduating from the five-year programme that was called

1 How quiet everything in Kääriku is with what silence / the windows the stairs and the grounds are silent the cracked asphalt keeps silent / under the ant paths how they are silent somewhere /everyone who was here spoke and recited poetry / how silent Juri Mikhailovich Alexander Moiseevich are / Linnart is silent and Haljand will not say a single word / and somewhere where I have not yet returned I am still there / March sun pricks and cuts my bare feet / while I young and in love run further and further / across the prickly snow towards our conciliar silence

2 See http://www.prixeuropeendelitterature.eu/kaplinski.html. 
'French Philology' in 1964. Besides publishing poetry, he penned fiction, dramas, texts of popular science and participated in discussions on linguistics, translation studies, Oriental studies (particularly as concerns the Far East), sociology and ecology. ${ }^{3}$ His notable role in mediating semiotic thinking in culture has prompted us to observe his activities in the context of semiotics in general.

Canonical descriptions of the Tartu-Moscow School of Semiotics and its activities in the 1960s and 1970s often tend to limit the list of its members on the Estonian side to a single person - Juri Lotman. At a closer look, however, it certainly appears that such an account is far from complete, as there were several Estonian scholars representing different academic backgrounds who directly contributed to the work of the school during its heyday in the period of 1964-1974: Igor Černov, Linnart Mäll, Ivar Kull, Uku Masing, and others. There was also a circle of local academics influenced by the school, who were instrumental in transferring the ideas of the semiotic school into the Estonian academic discourse and thus contributed to the local intellectual support to the school. The latter included a group of young linguists who gravitated to the work of Huno Rätsep, who taught structural linguistics at the University of Tartu in the 1960s, as well as participants in the seminar called Generative Grammar Work Group. Listed among these scholars were Haldur Õim, Mati Hint, Arvo Krikmann, Tiit-Rein Viitso, Pärt Lias, Leo Võhandu and others - no to mention Jaan Kaplinski.

Kaplinski was not a semiotician by profession or formal training, but he maintained important contacts with some of the members of the Tartu-Moscow School. Even though he would later become a renowned poet and author of both fiction and literary non-fiction, in the 1960s he entertained doubts about his choice of career, feeling uncertain whether to opt for a poetic or an academic vocation. He was certainly interested in linguistics, and there was much in his linguistic interests - which also involved reflections on texts and signs - that would bring him closer to the participants of the Tartu-Moscow School. He has also expressed regret that, instead of French, he did not enroll at the university as a student of Russian language and literature. Nevertheless, although Jaan Kaplinski did not become a linguist or a semiotician, some episodes from the history of the Tartu-Moscow School of Semiotics, as well as some semiotic concepts in general, are reflected in his literary work. He also had an opinion on how the concepts developed by the Tartu-Moscow semioticians could be applied to the study of Estonian culture and cultural history - work that in his regard was still waiting to be carried out.

3 On him and his writings, see e.g. Salumets 2014 in English; Soovik 2015a, 2015b, 2016 in Estonian. 
In addition to the legendary Kääriku Summer Schools on secondary modelling systems, Kaplinski also participated in the significant biosemiotic meeting "Biology and Linguistics", held in Tartu in February 1978. In 2000 he gave a talk at a seminar on semiotics of nature, also arranged in Tartu, and in June 2007 he delivered a keynote lecture "Two types of human communication" at the 9th World Congress of Semiotics in Finland. In the autumn of 2012, he contributed to the vivid academic scene of the Department of Semiotics at the University of Tartu by giving a lecture series titled "Languages, cultures, and thought".

Below, we reproduce, in English translation, some excerpts from the originally Estonian-language conversation with Jaan Kaplinski that took place at his country house at Mutiku, Estonia, on 7 January 2018 (for the full interview, see Kull, Velmezova 2018).

\section{When did your first come in contact with semiotics?}

Jaan Kaplinski: I got acquainted with semiotics when I was a student. But my first more significant contact with semiotics took place at a semiotics Summer School at Kääriku in $1964 .{ }^{4}$ I think Igor Černov was an important link between me and Lotman.

At the time you published several scholarly articles in the edited collections of the generative grammar work group, didn't you?

Jaan Kaplinski: I did that a little earlier, linguistics still interests me now, ${ }^{5}$ if I could, I would do more... I have my own point of view here, something like a linguistic typology; I wrote about Celtic and Finno-Ugric parallels and so on. I then read a lot on Finno-Ugric and Celtic Studies ... But the orthodox structuralism that they were engaged in at the time did not suit me. It's boring and, in fact, has no perspective, because it's just plain wrong to approach language in this way. As far as semiotics is concerned, it really gave people an opportunity to do things that would otherwise have remained impossible.

Did you attend Lotman's lectures?

Jaan Kaplinski: I did not regularly attend his lectures, but I have attended his talks many times.

4 Jaan Kaplinski wrote a review of this event for the journal Keel ja Kirjandus [Language and Literature] (Kaplinski 1964).

5 See Kaplinski 2020. 
Did you only go to the already mentioned Summer School at Kääriku or did you also visit some later schools?

Jaan Kaplinski: I visited others as well. One day, it was in spring, there was a school at Kääriku that was devoted mainly to Oriental studies. But many of the participants of the semiotic meetings were present as well ${ }^{6}$. It was at Kääriku that I became in touch with them; then, when I worked at the university's sociology laboratory [in the early 1970s], I went to Moscow to work at the libraries there. In Moscow, I visited Pyatigorskij, and after that I developed a close contact with him. ${ }^{7}$ Afterwards I visited him in London several times.

What do you think was the most important thing that Lotman and the Tartu-Moscow School achieved?

Jaan Kaplinski: One of their undoubted achievements was that they opened up the way to free thought, as those who were somehow connected with them in one way or another - like Linnart Mäll, for example - mostly weren't semioticians at all. Pyatigorskij, in my opinion, was not a semiotician either... He was an Orientalist and a philosopher - or rather, a philosopher and an Orientalist. And me, too, I don't really know semiotics, I'm a linguist. I am interested in the problems of semantics - for example, how and how often the names of body parts are used metaphorically in Eurasian languages. In the broadest sense of the word, this is, of course, semiotics - it is meaning that is being investigated here. Studying a language without studying meaning is no good.

\section{Did you read Saussure at the university?}

Jaan Kaplinski: Yes, it was not difficult for me: I spoke French well. ...

In many cases, the [language] sign is really arbitrary. When we say, for example, 'saba', the Estonian word itself is unlikely to be associated with the tail as such. Or, for example, when we speak German: 'das Auge', 'die Nase', 'der Mund'... Today, why in one case we have 'die', in another - 'der', and in yet another - 'das', is not determined by anything. There are many examples of arbitrariness.

There is a phenomenon in the Estonian language that particularly interested me - this phenomenon is ideophony, it is my favorite topic in linguistics. ${ }^{8}$ If we open the Estonian etymological dictionary, we will immediately see the expression 'phonetically motivated' ('häälikuliselt motiveeritud'). And I counted them,

6 This may have been a reference to the third semiotic Summer School which took place in Kääriku on 10-20 May 1968.

7 Thomas Salumets briefly evokes Jaan Kaplinski's relationship with Lotman and Pyatigorskij as well (Salumets 2014: 58, chapter "Erudite critic of culture - a walking contradiction").

8 See Kaplinski 2010. 
these "phonetically motivated" stems comprise some 20 per cent or even more. This phenomenon is typical of the Finno-Ugric languages, as well as of Korean and Japanese languages, to some extent also of Chinese, and in the Dravidian languages there is a lot of ideophony too. It is even more common in Finnish than in Estonian - but in Finnish, ideophony is presented a little differently... You can speak Finnish dryly - not in an official-sounding, but just neutral manner. And you can speak brightly, using ideophonic words - as, for example, in a poem by Ilmari Kianto about the northern lights: "Ne leimuaa, ne loimuaa ...".

In what way, then, was Saussure important to you?

Jaan Kaplinski: His book organized a lot for me. In the end, it all became so self-evident that I just got used to it - synchrony, diachrony... This even has a connection with Buddhist philosophy: everything is connected with everything. Each and every thing is a denial of all other things, so to speak...

I have the feeling that many things could be studied in the framework of another paradigm, and I don't know how much the semiotic paradigm allows to explain things that other paradigms do not. Yet apparently it allows quite a lot. More I cannot say. It is also interesting how semiotics makes it possible to combine so different phenomena as Jakob von Uexküll and Ferdinand de Saussure. To build bridges, interdisciplinary bridges - this alone is very important in today's world of over-specialization.

You have not been writing much about semiotics, but you have written a piece in Russian, entitled "Действительные числа" (Real numbers), ${ }^{9}$ in which you speak about the Tartu-Moscow School, and in addition, semioticians are mentioned in a poem you wrote in Russian ${ }^{10} \ldots$

Jaan Kaplinski: "Действительные числа" is a short story which is something of an expression of sympathy for all these people on my part. I have a somewhat Nabokovian aspiration in me to write about people who are a little crazy - 'with a birdie' ('linnukesega'), as they say in Estonian. The protagonist of "Действительные числа" is just that.

Why do you think there were so few Estonians who were drawn to Lotman? Jaan Kaplinski: Estonians kept to their own bubble, their Estonian bubble. In retrospect, this seems to have been wrong, and I was relatively internationally minded on my part. After all, I grew up on Russian literature, and it was a stupid

9 Kaplinski 2000.

10 See the epigraph on p. 608 of this issue. 
thing to do to go to study French. ... I should have opted for Finno-Ugric studies I was quite energetic, I could have travelled across Russia visiting Finno-Ugric peoples and collecting material, such things are of a great value for the posterity. Or else I could have taken up Russian language and literature, in this case I would naturally have reached Lotman. But what happened, happened. ... There were two places where one could seriously commit to studying philology - with Lotman and with Ariste $^{11} \ldots$

And of course, Russian semioticians did not feel much noticeable interest in what was so important for Estonians, in our own culture, history, desire for independence - all this remained alien to them. Although "the semiotics of being Estonian" could be a very interesting research topic.

What, in your opinion, was the most important or the most interesting thing about Lotman all in all?

Jaan Kaplinski: His charisma! Many of his theoretical views were, perhaps, too schematic, he could hover too far off from facts, yet at the same time he was a wonderful specialist in the history of culture. This is the best thing he has done, and this is what will live the longest. And how easy it was to get through to him...

And they should have addressed Estonian material - authors like Oskar Luts or Tammsaare as far as I am concerned, and studied Estonian material from this aspect... But none of them trusted themselves to do this... And they did not have many Estonian students, so they could have just employed Lotman's methods, as it were, the way he treated cultural history, observe something in the evolution of Estonian culture from a semiotic perspective, and this has not happened yet. For instance, the opposition of and the relations between 'one's own' and 'the other'. Or take the oppositions that have determined the Estonian culture: the orientation to the West or the East, the self and the other and many other topics, Southern and Northern Estonia, for example.

This work is not yet done. Lotman's legacy has been travelling around the world, but as far as I know, our own, Estonian culture has not been studied from a semiotic perspective yet...

\section{Instead of a postscript}

"Lotman was right when he argued that prose is more complex than poetry," Kaplinski (2004: 361) said in connection with his literary work. The essay "Kirjanduse tähendusest" ('On the meaning of literature') (Kaplinski 1968), one

11 Paul Ariste was a linguist, specialist in Finno-Ugric languages. 
of the earliest examples of Kaplinski's ties to semiotics, can be considered a publication in which the understanding of the role of literature and art is discussed from Lotman's perspective in many respects.

Later, Kaplinski would draw on his reflections on Ludwig Wittgenstein to write a treatise entitled 621 (Kaplinski 1992). One of the few people to have provided indepth analysis of this text was the Estonian theoretical physicist and philosopher Madis Kõiv (Kõiv 2001). In Kaplinski, he saw a potential disciple not so much of Lotman, but of Viktor Shklovskij, placing the renowned Russian formalist in the same - not just metaphorical, but also geographical - space with another mentor of Kaplinski's, theologian and poet Uku Masing who is behind the figure of the Teacher in Kaplinskiss novel The Same River (Kaplinski 2009[2007]). This is what Kõiv wrote:

It would be better, for instance, to have Viktor Shklovskij settle in the post-war Tartu, because in the case of Lotman, whose student he [Jaan Kaplinski] would have liked to be, some issues of incompatibility ["ómblemisraskusi”] would arise. Let there be Shklovskij in Lotman's place, this would not mean any significant difference in the primary tuition delivered; after his withdrawal from Moscow, he could land in Hurda Street ${ }^{12}$ ("in exile") right after the war, and, since in the immediate post-war years there would not have been a sufficient, and sufficiently well educated, Russian-speaking environment here, young K. as his student could serve as a good consolation for him; as for language, I suppose no difficulties would arise in case of two people so sensitive to it. (Kõiv 2001: 92)

\section{References}

Kaplinski, Jaan 1964. Semiootika suvekoolist Käärikul. [On a semiotics summer school in Kääriku.] Keel ja Kirjandus 12: 764-765.

Kaplinski, Jaan 1968. Kirjanduse tähendusest. [On the meaning of literature.] Looming 3: 432-441.

Kaplinski, Jaan 1992. 621. Looming 11: 1499-1544.

Kaplinski, Jaan 2000 = Каплинский, Яан 2000. Действительные числа. [Real numbers.] Звезда: Литературный и общественно-политический журнал 11: 88-100.

Kaplinski, Jaan 2004. Kõik on ime. [Everything is a miracle.] (Salumets, Thomas, ed.; Eesti mõttelugu 55.) Tartu: Ilmamaa.

Kaplinski, Jaan 2009[2007]. The Same River. [Seesama jõgi.] (Wilson, Susan, trans.) London, Chester Springs: Peter Owen.

Kaplinski, Jaan 2010. Ideofoonidest meil ja mujal. [On ideophones with us and elsewhere.] Keel ja Kirjandus 2: 133-136.

Kaplinski, Jaan 2014 = Каплинский, Яан 2014. Белье бабочки ночи / Бплые бабочки ночи. [White butterflies of night.] Таллинн: Kite.

12 This is the street in which Uku Masing lived. 
Kaplinski, Jaan 2020. Eesti, estoranto ja teised keeled. [Estonian, Estoranto and other languages.] (Bibliotheca controversiarum.) Tallinn: Tallinna Ülikooli Kirjastus.

Kull, Kalevi; Velmezova, Ekaterina 2018. Jaan Kaplinski ja semiootika. [Jaan Kaplinski and semiotics.] Acta Semiotica Estica 15: 194-211.

Kõiv, Madis 2001. Nõnda lausus Jaan Kaplinski. [Thus said Jaan Kaplinski.] Looming 1: 73-101.

Salumets, Thomas 2014. Unforced Flourishing: Understanding Jaan Kaplinski. Montreal: McGill-Queen's University Press.

Soovik, Ene-Reet 2015a. Kodukoht ja teeleidmine: Kaplinski kirjutatust. [Home and wayfinding: On Jaan Kaplinki’s writings.] Keel ja Kirjandus 58(2): 73-87.

Soovik, Ene-Reet 2015b. Kahest aiast ja mõnest mullast: Kaplinski aiad ja peenramaad. [Two gardens and several soils: Kaplinskis gardens and vegetable plots.] Keel ja Kirjandus 58(11): 765-776.

Soovik, Ene-Reet 2016. Kaplinski kaugused. [Kaplinski's far-away spaces.] Keel ja Kirjandus 59(2): 114-126. 